\title{
Determination of tritium concentration in aquatic environment using solid polymer electrolyte
}

\author{
M. Saito, K. Fujita and M. Fukui \\ Research Reactor Institute, Kyoto University, Kumatori-cho, \\ Sennan-gun, Osaka 590-0494, Japan
}

\begin{abstract}
An electrolysis apparatus utilizing solid polymer electrolyte (SPE) was used to enrich HTO contained in various aquatic samples collected from Kansai area in the vicinity of KURRI (Kyoto University Research Reactor). Usually $1 \mathrm{~L}$ of distilled sample was condensed to about $48 \mathrm{ml}$ by electrolysis. Under this condition, tritium in the sample water was ten-fold enriched. The tritium concentration in river water in the summer season distributed between 0.4 and $1.3 \mathrm{~Bq} / \mathrm{L}$. The tritium enrichment system using SPE was found to be convenient to assay aquatic HTO.
\end{abstract}

\section{INTRODUCTION}

In this century, forthcoming problems concerning foods, environments and energy resources are among greatest concerns of human beings. To cope with possible exhaustion of fossil fuels and global warming due to increasing carbon dioxide in the atmosphere, one of the promising choices is the utilization of fusion energy. However, one of the prerequisite problems to give reality to the dream of fusion energy is the safety of tritium that is used as the fuel of the fusion reactor.

In the future possible development of the fusion reactor, the safety analysis of tritium that is released to environment is a main concern of health physicists since a huge amount of tritium is used as fuel and considerable amount of tritium will be released from fusion facilities accidentally and chronically. Precise determination of tritium level in aquatic environment is prerequisite for pre-assessment of the hazardous effect of tritium to biosphere and humans. The released tritium exists in the biosphere mainly as tritiated water (HTO). Today, averaged level of environmental HTO in our country is reportedly around $0.5-1.0 \mathrm{mBq} / \mathrm{ml}$. The measurement of environmental tritium is rather time-consuming since tritium enrichment is necessary when LSC system and ordinarily $20 \mathrm{ml}$ or occasionally $100 \mathrm{ml}$ sample vials are used for tritium assay of enriched samples. Recently a convenient and safe apparatus for tritium enrichment using solid polymer electrolyte (SPE) was developed [1]. The enrichment process using this apparatus is different from the conventional electrolysis using alkaline solution (ASE). The conventional method has some difficulty in its performance as follows.

a. The procedure for analysis is complicated.

b. Maximum tritium enrichment ratio is solely determined by the upper limit of the concentration of electrolyte in the electrolysis solution..

c. As products of electrolysis, hydrogen and oxygen gasses are produced as a mixture gas that has high risk of explosion.

The SPE has been originally developed as a fuel cell. Sulfonic groups grafted to a polymer material bear inic conduction. Water molecule is decomposed at the anode and the produced hydrogen atom moves to the cathode through the polymer. Thus oxygen and hydrogen gasses produced are exhausted by separate lines. Additionally, the SPE can be used repeatedly. Other advantages of this system are mentioned in detail in a literature [1]

In the present study, a SPE electrolysis apparatus was used to determine the tritium level in the iquatic environment surrounding Kyoto University Research Reactor Institute (KURRD) and other interesting locations in Japan.

\section{MATERIAL AND METHODS}

A SPE electrolysis apparatus was purchased from Permelec Co, Fujisawa. River water and other surface water for comparison were sampled at the various sampling points mainly in summer season. 1 . About two liters of the sample water was distilled and each $1 \mathrm{~L}$ of the distilled water was subjected to SPE clectrolysis. The electric current for electrolysis was set at $60 \mathrm{~A}$. The final volume of the water after intium enrichment was $48 \mathrm{ml}$. Electrolysis procedure was finished automatically by a water level sensing 
system. About 45 hours is needed for each run of the apparatus. According to Kaufman and Libby [2], the volume of solution, the tritium concentration, and tritium separation factor $\beta$ are related to each other by the following equation.

$$
\mathrm{T} / \mathrm{T}_{0}=\left(\mathrm{V}_{0} / \mathrm{V}\right)^{1-1 / \beta}
$$

where

$\mathrm{T}=$ final tritium concentration $(\mathrm{Bq} / \mathrm{L})$,

$\mathrm{T}_{0}=$ initial tritium concentration $(\mathrm{Bq} / \mathrm{L})$,

$\mathrm{V}=$ final volume of solution $(\mathrm{ml})$, and

$\mathrm{V}_{0}=$ initial volume of the solution $(\mathrm{ml})$.

In the present enrichment system, unfortunately the final volume of the solution can not be determined because some volume of the solution remains in the apparatus after completion of enrichment. Therefore, we determined the tritium enrichment ratio directly using dilute tritiated water contaning tritium component of $5-70 \mathrm{~Bq} / \mathrm{L}$. One liter of the sample solution was enriched to the final volume of about $48 \mathrm{ml}$ and the tritium concentration was determined. The tritium enrichment ratio averaged for four determinations was $10.0 \pm 0.8$.

After tritium enrichment, $10 \mathrm{ml}$ of the sample was mixed with $10 \mathrm{ml}$ of liquid scintillation cockial (Picofluor, Packard) and subjected to tritium assay using a liquid scintillation counter (Tricarb2750TR, Packard). The counting time was $200 \mathrm{~min}$ for each sample. For individual water samples, the counting sample was triply prepared. Under these conditions, the detection limit of tritium for the field sample was $0.16 \mathrm{~Bq} / \mathrm{L}$. Sampling of the surface water was made in the summer season after the rainy season to reduce the influence of rainfall on the tritium level. For the river water, sampling points were focissed on two rivers. One is Inunakigawa (means Dog Crying River) that is located about $4 \mathrm{~km}$ southeast to KURRI and another one is Arida River.

To ensure the reliability of the SPE method, same samples were sujected to SPE and ASE.

\section{RESULTS AND DISCUSSION}

The result is summarized in Table.1. The tritium concentration of Inunakigawa (Inunaki river) averaged for the summer season was $0.83 \pm 0.30 \mathrm{~Bq} / \mathrm{L}$ and that for Aridagawa (Arida river) was $0.77 \pm 0.17 \mathrm{~Bq} / \mathrm{L}$. For comparison, the tritium concentration in the surface water collected at various sampling points in the vicinity of KURRI during the period 1988-1999 and measured by the conventional ASE electrolysis method are presented in Fig.1. The tritium in the aquatic system has a general tendency to decrease to the level before nuclear experiments at 1950's.

Evaluation of the background level tritium in the environment is required before introducing fusion facilities to estimate the expected impact to human health of tritium that might be released accidentally or chronically from the facilities. The tritium level in the aquatic system is influenced by many factors, such as rainfall, water reservoir size in local environment, tritium metabolism in living things, and weather condition and so on. As shown in Fig.1., the tritium concentration in surface water distributes between 0.3 and $1.0 \mathrm{Bg} / \mathrm{L}$. This level could be considered the ordinary level of surface water, Some samples, obtained from Ameyamagawa for instance, obtained in late autumn season exhibited low trituin concentration compared with the samples of summer season. This fact may reflect the seasonal variane of atmospheric tritium. The tritium concentration in atmospheric moisture and precipitation extibis significant seasonal variance. Kimura found tritium in the atmospheric moisture is high in summer seas0: and low in winter season [3]. Tritium level in the river depends also on the residence time of water in the aquifer. To identify the origin of tritium in surface water at the environmental level, a set of data including tritium level in the precipitate, surface water must be obtained. The deuterium isotope atio will offer useful information on the origin of the water sample that we are targeting.

From the present study, it was found that the SPE apparatus is convenient for tritium assay of environmental water samples. As shown in Table 2. the data obtained by the SPE method agreed well with the data obtained by the conventional ASE method. However, attention must be paid for traci amount of still unidentified disturbing substances existing in the sample. Distillation of the sample atter SPE enrichment was found to reduce such effects. 
Table 1. Tritium concentration determined by SPE method

\begin{tabular}{|c|c|c|c|}
\hline Category & Sapmpling point & Date & Tritium $(\mathrm{Bq} / \mathrm{L})$ \\
\hline Hot spring & Jintsu $(350 \mathrm{~m})$ & $9 / 2 / 01$ & $<0.16$ \\
\hline Lake & Ooike & $8 / 11 / 99$ & 0.89 \\
\hline Lake & Ooike & $27 / 11 / 00$ & 0.32 \\
\hline Ocean & Minabe & $1 / 4 / 99$ & 0.53 \\
\hline Ocean & Katsuura-Bousou & $26 / 5 / 99$ & 0.71 \\
\hline Ocean & Kaizuka & $1 / 7 / 99$ & 0.83 \\
\hline Ocean & Kaizuma & $20 / 8 / 99$ & 0.63 \\
\hline \multirow[t]{2}{*}{ River } & Ameyamagawa- & $9 / 11 / 99$ & 0.54 \\
\hline & Nakashou & & \\
\hline \multirow[t]{2}{*}{ River } & Ameyamagawa- & $27 / 11 / 00$ & 0.38 \\
\hline & Nakashou & & \\
\hline \multirow[t]{2}{*}{ River } & Ameyamagawa- & $27 / 11 / 00$ & 0.40 \\
\hline & Shouhei & & \\
\hline \multirow[t]{3}{*}{ River } & Ameyamagawa- & $14 / 8 / 00$ & 0.64 \\
\hline & Houjou & & \\
\hline & Average & \multicolumn{2}{|c|}{$0.49 \pm 0.12$} \\
\hline River & Aridagawa-Sawa & $15 / 8 / 99$ & 0.68 \\
\hline River & Aridagawa-Shimidzu & $15 / 8 / 99$ & 1.00 \\
\hline River & Aridakawa-Kawaguchi & $27 / 7 / 99$ & 0.87 \\
\hline River & Aridakawa-Kusu & $4 / 8 / 99$ & 0.71 \\
\hline River & Aridakawa-Shiraishi & $27 / 7 / 99$ & 0.87 \\
\hline River & Aridakawa-Shiraishi & $9 / 8 / 99$ & 0.45 \\
\hline River & Aridakawa-Shiraishi & $1 / 9 / 99$ & 0.87 \\
\hline \multirow[t]{2}{*}{ River } & Ariidakawa-Kusu & $4 / 8 / 99$ & 0.71 \\
\hline & Average & \multicolumn{2}{|c|}{$0.77 \pm 0.17$} \\
\hline River & Inunaki & $22 / 8 / 00$ & 0.66 \\
\hline River & Inunaki & $21 / 8 / 00$ & 0.42 \\
\hline River & Inunaki-Hakuunn & $13 / 8 / 00$ & 0.88 \\
\hline River & Inunaki-Hudoushita & $21 / 8 / 00$ & 0.64 \\
\hline River & Inunaki-Hudoushita & $12 / 8 / 00$ & 0.52 \\
\hline River & Inunaki-Hudoushita & $21 / 8 / 00$ & 0.62 \\
\hline River & Inunaki-Ikedabashi & $22 / 8 / 00$ & 1.33 \\
\hline River & Inunaki-Ikedabashi & $12 / 8 / 00$ & 0.59 \\
\hline River & Inunaki-Jintuu & $22 / 8 / 00$ & 0.74 \\
\hline River & Inunaki-Kurinoki & $13 / 8 / 00$ & 0.93 \\
\hline River & Inunaki-Oogi & $22 / 8 / 00$ & 0.88 \\
\hline River & Inunaki-Sawa & $12 / 8 / 00$ & 0.58 \\
\hline River & Inunaki-Sawa & $4 / 8 / 00$ & 0.57 \\
\hline \multirow[t]{2}{*}{ River } & Inunaki-Sawa & $13 / 8 / 00$ & 0.39 \\
\hline & Average & \multicolumn{2}{|c|}{$0.83 \pm 0.30$} \\
\hline
\end{tabular}


Table 2. Comparison of ASE and SPE

\begin{tabular}{llll}
\hline Sampling point & Date & $\begin{array}{l}\text { Concentration } \\
\text { determined by } \\
\text { ASE }(\mathrm{Bq} / \mathrm{L})\end{array}$ & $\begin{array}{l}\text { Concentration } \\
\text { determined by SPE } \\
(\mathrm{Bq} / \mathrm{L})\end{array}$ \\
\hline Ooike & $27 / 11 / 00$ & $0.33 \pm 0.03$ & $0.32 \pm 0.09$ \\
Nakashou bridge & $27 / 11 / 00$ & $0.38 \pm 0.04$ & $0.40 \pm 0.03$ \\
Shouhei bridge & $27 / 11 / 00$ & $0.35 \pm 0.03$ & $0.40 \pm 0.06$ \\
\hline
\end{tabular}

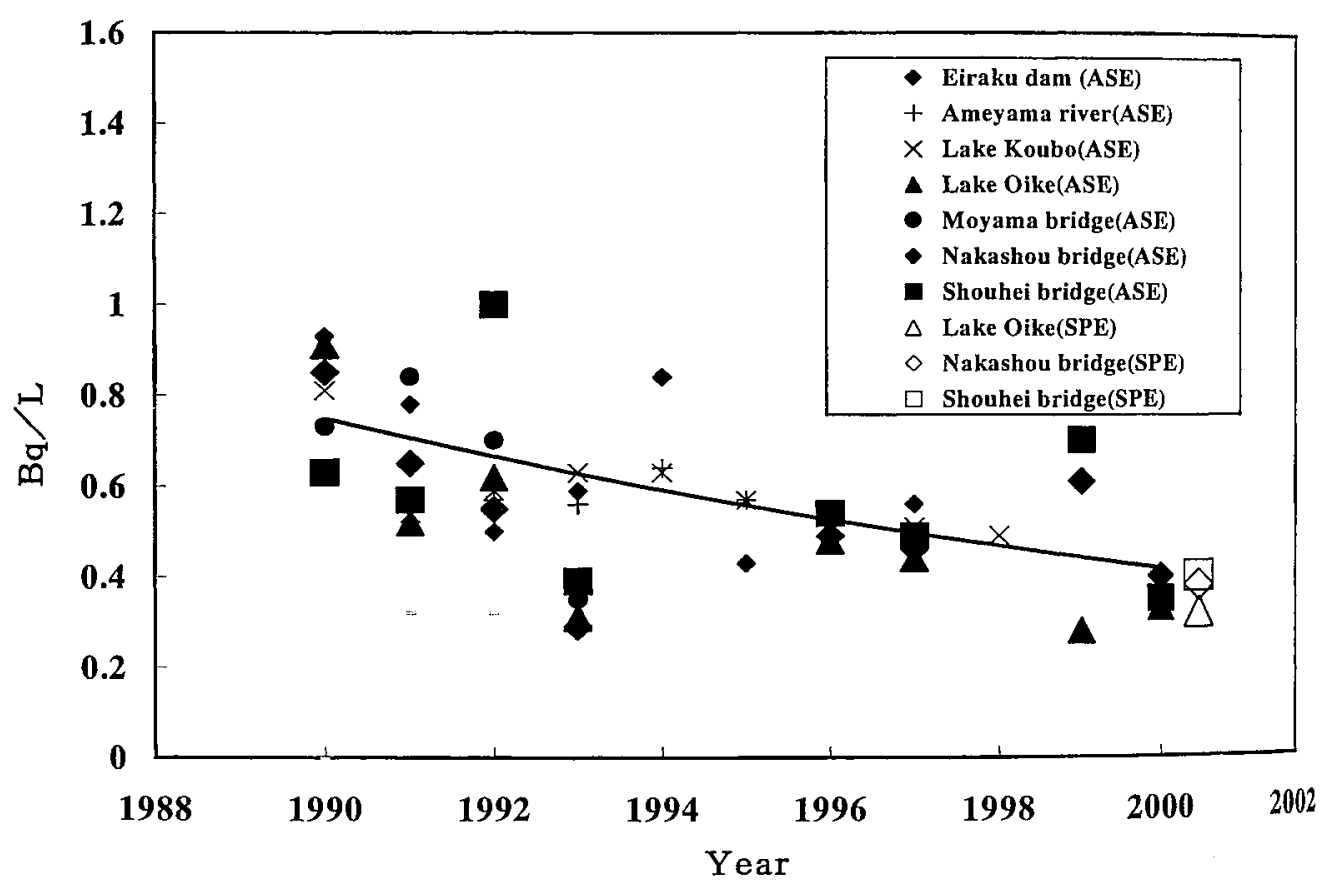

Fig.1 Tritium concentration in river water.

\section{REFERENCES}

1.M.Saito, In:Proceedings of the $5^{\text {th }}$ Low Level Counting Conference Using Liquid Scintillation Analysis, June 20-21, 1996. ( Packard Instrument Co.;1996), p.102.

2.S.Kaufman, W.F.Libby, Physical Review 93,1337(1954)

3.H.Kimura,T.Kon,M.Sasaki, in Proceedings of the International Workshop on Distribution and Speciation of Radionuclides in the Environment, Rokkasho,Aomori,Japan, October 11-13, edited by J.Inaba,S.Hisamatsu, Y.Ohtsuka, p.326. 